\title{
Potential of Ricinus communis L. For Removal of Heavy Metal in Contaminated Soil
}

\section{*1AKINTOLA, OO; ${ }^{1} \mathrm{ABIOLA}$, IO $;{ }^{1} \mathrm{ABODUNRIN}, \mathrm{EK} ;{ }^{1}$ OLOKEOGUN, OS; ${ }^{1}$ EKAUN, AA; ${ }^{1}$ ADEMIGBUJI, AT ; ${ }^{2}$ BABATUNDE, KO}

\author{
${ }^{I}$ Federal College of Forestry, Ibadan, Oyo State, Nigeria \\ ${ }^{2}$ Federal College of Wildlife Management, New-Bussa, Niger State, Nigeria \\ *Corresponding Author Email: toyinakintola73@gmail.com
}

\begin{abstract}
S: Heavy metal contamination has become a serious ecological problem due to its toxic effects on soils, plants and human. Experimental study was conducted on dumpsite soil to assess the potential of Ricinus communis to accumulate heavy metals from the soil using bioconcentration (BCF) and tanslocation factors (TF). Heavy metals concentration (mg/kg) in dumpsite and control soil before planting were $\mathrm{Mn}$ (50.68- 220.08); $\mathrm{Zn}(29.01-135.56)$; $\mathrm{Cu}$ (8.92- 86.88), $\mathrm{Pb}$ (5.88-48.86), $\mathrm{Ni}(3.01-7.99)$ and $\mathrm{Co}(1.78-6.88)$ while the concentration in soils after planting were $\mathrm{Mn}(29.89-135.21) ; \mathrm{Zn}(15.11-88.21)$; $\mathrm{Cu}(3.89-50.22)$, pb (3.68-31.56), Ni (1.22-3.56) and Co (0.67-2.68) in $\mathrm{Mg} / \mathrm{kg}$.Ricinus communis showed $\mathrm{BCF}$ greater than 1 for $\mathrm{Ni}$ and $\mathrm{Co}$ and less than 1 for $\mathrm{Mn}, \mathrm{Cu}, \mathrm{Zn}$ and $\mathrm{Pb}$ while $\mathrm{TF}$ is greater than 1 for all the determined heavy metals. The dumpsite soils have higher heavy metal concentration than the control soil. The levels of heavy metals concentration in soils and plants are in the order of $\mathrm{Mn}>\mathrm{Zn}>\mathrm{Cu}>\mathrm{Pb}>\mathrm{Ni}$. Significant reduction $(\mathrm{P}<0.05)$ was observed in the heavy metal concentrations in the soils before and after planting indicating their accumulation in the plants. Results of this study indicate the accumulation of heavy metals inRicinus communis plants and its potential for effective removal of $\mathrm{Cu}, \mathrm{Zn}, \mathrm{Pb}, \mathrm{Ni}, \mathrm{Co}$ and $\mathrm{Mn}$ from the dumpsite soils.
\end{abstract}

DOI: https://dx.doi.org/10.4314/jasem.v25i3.10

Copyright: Copyright (C) 2021 Akintola et al. This is an open access article distributed under the Creative Commons Attribution License (CCL), which permits unrestricted use, distribution, and reproduction in any medium, provided the original work is properly cited.

Dates: Received: 12 December 2020; Revised: 26 January 2021; Accepted: 12 February 2021

Keywords: Heavy metal accumulation, Ricinus communis, Dumpsite soil, Translocation factor, Remediation

Increase in population has led to rapid urbanization growth and industrialization development in most cities of the world. This has led to increase in the quantities of solid wastes generated and has constituted a major environmental problem such as heavy metal contamination. Heavy metal contamination from solid wastes has become a severe ecological problem with increasing interruption of natural biogeochemical cycles due to their nonbiodegradable nature (Akintola, 2014; Gworek et al., 2016; Zhu et al, 2016). The influence of human activities on the ecosystem has been recognized as one of the major cause of heavy metal contamination (Mazur et al., 2015; Yin et al., 2016). Consequently, heavy metal contamination has become a significant threat to the environment and human health due to their slow biodegradability, easy bioaccumulation and hightoxicity (Akintola and Bodede, 2019a; Adamcova et al., 2019). Solid wastes can decompose wide varieties of contaminants which can extensively affect the environment and human health (Sing et al., 2011). The improper management of waste dumpsites in many countries of the world has led to heavy metals contamination due to leachates that emanate from the decomposition of the deposited wastes (Akintola, 2014; Bartkowiak et al., 2016, Famuyiwa et al., 2018).
Higher levels of heavy metal concentrations in soils from dumpsites and their ecological effects has been reported by several researchers (Akintola and Bodede, 2019b; Famuyiwa et al., 2018, $\mathrm{Hu}$ et al., 2018; Akintola et al., 2020). Ajakanga dumpsite and its environ has been reported to have elevated concentrations of heavy metals due to anthropogenic influence of the wastes (Oguiseju et al., 2015; Ganiyu et al., 2016, Ewemoje et al., 2017; Akintola and Bodede 2019a). Akintola and Bodede (2019a) in their study indicated no to low heavy metal pollution level in the vicinity of Ajakange dumpsite and no probable health risk was observed as the total hazard index of all the heavy metals was less than one. However, they indicated rremediation techniques should be applied to reduce the mobility of heavy metals in the contaminated soils and to decrease the likely uptake of these heavy metals by plants and oral ingestion by human in the study area. Remediation of polluted soils is a demanding task, however several methods such as mechanical removal and chemical engineering has been used but they are costly and only useful depending on the structure and fertility of the soil (Gaur and Adholeya, 2004). Using of plants for removal of pollutants from the soil and water is presently used as a substitute for soil clean-up 
(Bauddh et al., 2015). Since they respond to higher concentration of contaminants such as heavy metals by different means of indication, exclusion or accumulation of elements thus, phytoremediation has the advantage of using the selective uptake potential of some plants through the root and rhizomes to remove or modify contaminants from the environment (Nawrot et al., 2019). Phytoremediation is a traditional method that is economically suitable, feasible, ecofriendly and improves the soil fertility by releasing various organic compounds. This study investigated the potential of Riccinus communis plants for removal of heavy metals in soils from Ajakanga dumpsite in Ibadan, South western Nigeria.

\section{MATERIALS AND METHOD}

Study area:Ajakanga dumpsite is an open waste disposal site located between $7^{\circ} 18^{\prime} 41.32^{\prime \prime} \mathrm{N}$ (latitude)

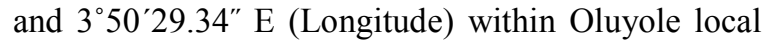
government, Ibadan south-western Nigeria (Akintola and Bodede, 2019a). Increase in population and rapid urbanization has opened the dumpsite to build up areas. The vegetation is tropical rain forest with thick undergrowth. The study area is drained by River Ona and its tributaries. The drainage pattern is dendritic. Ajakanga waste dumpsite and its environs are underlain by biotite-hornblende gneiss, migmatite gniess and quartzite (Ogunseiju et al., 2015). Previous studies conducted in this area revealed elevation increased in heavy metals concentration due to the dumpsite (Oguiseju et al., 2015; Ganiyu et al., 2016, Ewemoje et al., 2017; Akintola and Bodede, 2019a).Composite samples were collected at $0-0.20 \mathrm{~cm}$ from different sampling points from the dumpsite and also from 500m (upslope) away from the dumpsite, this serve as control.

Sample Preparation and Analysis: The samples were air dried and sieved to less than $2 \mathrm{~mm}$ to remove the larger stones and other root materials. Samples were analyzed for particle sizes using hydrometer method (Brown, 2009), soil pH was determined using electrode $\mathrm{pH}$ meter in 1-1 water- soil solution while the organic carbon contents of the soils were determined using Walkely and Black (1934). The concentrations of heavy metals $(\mathrm{Zn}, \mathrm{Cu}, \mathrm{Mn}, \mathrm{Pb}, \mathrm{Ni}$ and $\mathrm{Co}$ ) were determined using Atomic Absorption Spectrophotometer (AAS) model Accufys 211.

Pot Experiment: Riccinus communis (castor) seeds were obtained from Igangan in Ibarapa Local Government area, Ibadan Oyo State. Before planting, the seeds have undergone treatment to break dormancy by immersing the seeds in warm water for $24 \mathrm{~h}$ at 40 ${ }^{\circ} \mathrm{C}$. Five seeds were directly sown in each pot containing $5 \mathrm{~kg}$ of dumpsite soils and control soils.
Riccinus communis plants were grown in a partially shaded location behind the Forestry Technology Department, Federal College of Forestry, Ibadan.

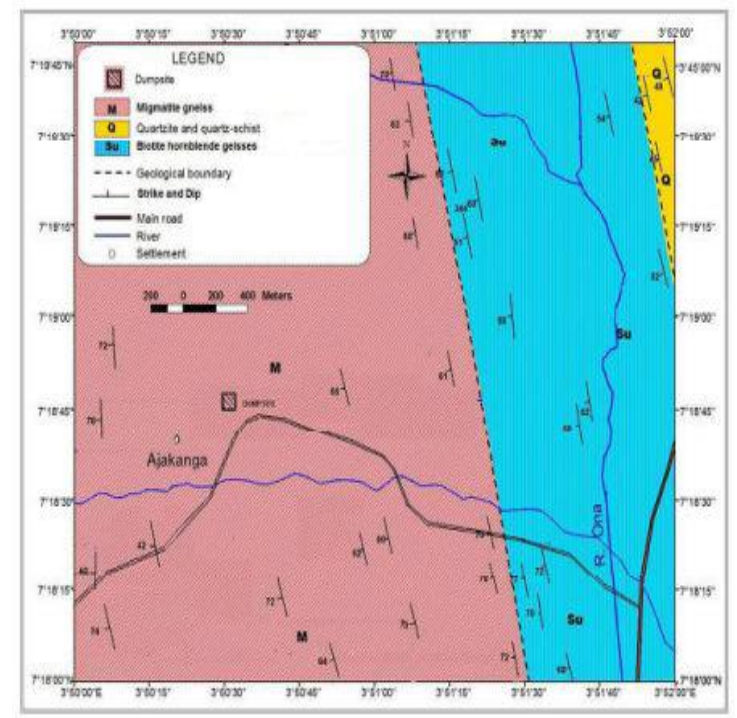

Fig 1. Geological map of the study area after Ogunseiju et al., (2015)

The experiment was replicated five times. All the pots were watered every 2-3 days based on the evaporative demand. Extreme care was taken to prevent water leakage from the pots. After 2 weeks of germination, one seedling was maintained in a pot until the end of the experiment. The plants Riccinus communis were harvested after 3 months of growth. The height of plant was measured from the ground level of the soil in the pot to the tip of the stem; leaf area, stem diameter, leaf production and plant biomass were also determined. After thoroughly removing the soil particles, roots and shoots were separated and repetitively cleaned with tap water followed by distilled water, dried for $72 \mathrm{~h}$ at $60{ }^{\circ} \mathrm{C}$, and then, the dry weights were measured. The dried roots and shoots were ground with mortar and pestle and stored for further analysis. The soil samples were taking after planting for heavy metal analysis. Both the plant and soil samples were analyzed for heavy metal using Atomic Absorption Spectrophotometer (AAS) model Accufys 211).

Data Analysis: Evaluation indices such as bioconcentration factor (BCF) and transloction factor (TF) were calculated for $\mathrm{Mn}, \mathrm{Zn}$. $\mathrm{Cu}$. Pb, Ni and $\mathrm{Co}$ to assess the phytoremediation potential of Riccinus communis. $\mathrm{BCF}$ is described as the ratio of heavy metal concentration in plant shoots to heavy metal concentration in soil as indicated in equation 1; the $\mathrm{BCF}>1$ is preferable according to Mertens et al.,(2005), while TF for heavy metal was calculated 
according to the equation 2 given by Stoltz and Greger (2002).

$\mathrm{BCF}=$ Heavy metal concentration in $\frac{\text { plants }}{\text { soils }}$

$\mathrm{TF}=$ Heavy metal concentration in $\frac{\text { Shoots }}{\text { Roots }} \quad 2$

Data were analyzed using analysis of variance (ANOVA). Separation of mean were done using Turkey test $(\mathrm{P}<0.05)$. All statistical analyses were done using. SPSS (Version 20.0, IBM, USA).

\section{RESULTS AND DISCUSSIONS}

Characteristics of soils Prior to Planting: The result of chemical analysis of the soil used for growing media is presented in Table 1. The texture of the soils is sandy loam, thus the soils are suitable for seedling growth and development due to the presence high nutrients, CEC and high water holding capacity (Akintola and Bodede, 2019b). The $\mathrm{pH}$ of the control and dumpsite soils was $6.70 \pm 0.36$ and $6.01 \pm 0.25$. The $\mathrm{pH}$ of the soils is alkalinic in nature. Organic matter content of soils before plantings of dumpsite (T2) and control (T1) were $6.11 \pm 0.71 \%$ and $4.67 \pm 0.33 \%$ respectively. These values were higher compared to similar works conducted by Yashim et al., (2016) Akintola and Bodede, (2019b) and Palanivel et al., (2020) and this bay be attributed to the differences in study location, topographic of the area, geological condition, types of deposited wastes, age of the dumpsites among others. The high organic matter content in the dumpsite soil can be attributed to decomposition and composting processes of the animals waste (which include animal's dung, body parts and blood),plants/vegetable matter and polymer or plastic materials (as the site is also used as a municipal solid waste dump) and also washed away agricultural chemicals (pesticides, insecticides and herbicides) that passed through the dump sit and this confirms why farmers consciously choose to farm on such site(Akintola and Bodede, 2019b). The concentration of heavy metals showed the order of $\mathrm{Mn}>\mathrm{Zn}>\mathrm{Cu}>\mathrm{Pb}>\mathrm{Ni}>\mathrm{Co}$ in the soils. The mean concentration of the studied heavy metals in the dumpsite soil were significantly higher than the control at $\mathrm{P}<0.05$. This indicates that the waste deposited in the site has contributed significantly to the heavy metals contamination of the soil and can be of health risk since crops are planted around the dumpsite.

Growth Performance: The growth parameters determined is presented in Table 2. The Riccinus communis plants showed notable growth performance in dumpsite soil (T1) with mean height value of $33.55 \pm$ $1.01 \mathrm{~cm}$ while its height in control soil (T2) is $25.33 \pm 0.67 \mathrm{~cm}$. The respective mean stem diameter of Riccinus communis in dumpsite and control soils were $1.76 \pm 0.05$ and $0.68 \mathrm{~cm} \pm 0.01$ while the man values of leaf area were $132.66 \pm 2.51$ and $100.05 \pm 1.09 \mathrm{~cm}^{2}$ respectively.

Table 1: Mean values of Physiochemical characteristics of soils before planting

\begin{tabular}{lll}
\hline Parameters & \multicolumn{3}{l}{ Treatments } \\
\cline { 2 - 3 } & $\begin{array}{l}\text { Dumpsite } \\
\text { soil (T1) }\end{array}$ & $\begin{array}{l}\text { Control soil } \\
(\mathrm{T} 2)\end{array}$ \\
\hline Clay $(\%)$ & $12 \pm 0.51^{\mathrm{a}}$ & $10 \pm 0.25^{\mathrm{a}}$ \\
Silt $(\%)$ & $16 \pm 0.89^{\mathrm{a}}$ & $12 \pm 0.41^{\mathrm{a}}$ \\
Sand (\%) & $73 \pm 1.51^{\mathrm{a}}$ & $78 \pm 2.11^{\mathrm{a}}$ \\
Textural type & Sandy loamy & Sandy loamy \\
$\mathbf{p H}$ & $6.70 \pm 0.36^{\mathrm{a}}$ & $6.01 \pm 0.25^{\mathrm{a}}$ \\
$\mathbf{O M}(\%)$ & $6.11 \pm 0.71^{\mathrm{a}}$ & $4.67 \pm 0.33^{\mathrm{b}}$ \\
$\mathbf{M n}$ & $220.08 \pm 2.51^{\mathrm{a}}$ & $50.68 \pm 0.86^{\mathrm{b}}$ \\
$\mathbf{Z n}$ & $135.56 \pm 1.51^{\mathrm{a}}$ & $29.01 \pm 0.11^{\mathrm{b}}$ \\
$\mathbf{C u}$ & $86.88 \pm 0.69^{\mathrm{a}}$ & $8.92 \pm 0.09^{\mathrm{b}}$ \\
$\mathbf{P b}$ & $48.86 \pm 0.27^{\mathrm{a}}$ & $5.88 \pm 0.05^{\mathrm{b}}$ \\
$\mathbf{N i}$ & $7.99 \pm 0.11^{\mathrm{a}}$ & $3.01 \pm 0.02^{\mathrm{b}}$ \\
$\mathbf{C o}$ & $6.88 \pm 0.08^{\mathrm{a}}$ & $1.78 \pm 0.5101^{\mathrm{b}}$ \\
\hline Different letters between columns are significantly different from \\
\multicolumn{2}{c}{ each other at $P<0.05 ;$ OM $=$ organic matter }
\end{tabular}

The mean values of leaf production of the plants in dumpsite and control soils were $28.11 \pm 0.91$ and $17.23 \pm 0.34$ respectively while the respective mean plant biomass in dumpsite and control soils wee $229.20 \pm 1.99$ and $176.12 \pm 1.12 \mathrm{~g}$ respectively. The significant higher growth parameters noticed in the dumpsite soil when compared to control soil could be attributed to higher amount of organic matter in the soil due to the decomposition of organic wastes and microorganism in the soils. The biomass of the plant varied significantly. The results showed that biomass production for plants gradually increased with treatments (Table 2). It showed that the amounts of heavy metals in the soils did not affect biomass production or induce phytotoxicity symptoms in the plant (Akintola and Bodede, 2019b). Heavy metal concentration in the growth media before and after planting: The results of heavy metal concentrations before and after planting were shown in Table3.

Heavy metals concentration $(\mathrm{mg} / \mathrm{kg})$ in dumpsite and control soil before planting were Mn (50.68-220.08); $\mathrm{Zn}$ (29.01- 135.56); Cu (8.92- 86.88), Pb (5.88-48.86), $\mathrm{Ni}$ (3.01-7.99) and $\mathrm{Co}(1.78-6.88)$ while the concentration in soils after planting were Mn (29.89135.21); Zn (15.11-88.21); Cu (3.89-50.22), pb (3.68$31.56)$, Ni (1.22-3.56) and Co (0.67-2.68) in $\mathrm{Mg} / \mathrm{kg}$. Observed reductions in the heavy metal concentrations in soil after planting can be attributed to the ability of Riccinus communis to uptake heavy metals from the soils. 
Table 2: Mean values of growth performance of Riccinus communis.

\begin{tabular}{llllll}
\hline Treatment & $\begin{array}{l}\text { Plant } \\
\text { Height }(\mathbf{C m})\end{array}$ & $\begin{array}{l}\text { Leaf } \\
\text { area }\left(\mathbf{C m}^{2}\right)\end{array}$ & $\begin{array}{l}\text { Stem } \\
\text { diameter }(\mathbf{C m})\end{array}$ & $\begin{array}{l}\text { Leaf } \\
\text { Production }\end{array}$ & $\begin{array}{l}\text { Plant } \\
\text { biomass }(\mathbf{g})\end{array}$ \\
\hline T1 & $33.55 \pm 1.01^{\mathrm{a}}$ & $132.66 \pm 2.51^{\mathrm{a}}$ & $1.76 \pm 0.05^{\mathrm{a}}$ & $28.11 \pm 0.91^{\mathrm{a}}$ & $229.92 \pm 1.99^{\mathrm{a}}$ \\
T2 & $25.33 \pm 0.67^{\mathrm{b}}$ & $100.05 \pm 1.091^{\mathrm{b}}$ & $0.68 \pm 0.01^{\mathrm{b}}$ & $17.23 \pm 0.34^{\mathrm{b}}$ & $176.2 \pm 1.12^{\mathrm{b}}$ \\
\hline \multicolumn{5}{c}{ Different letters between rows are significantly different from each other at $P<0.05$}
\end{tabular}

Table 3: Heavy Metal Concentration in the soil before and after planting

\begin{tabular}{|c|c|c|c|c|}
\hline \multirow{2}{*}{$\begin{array}{l}\text { Heavy } \\
\text { metals in } \\
\mathrm{mg} / \mathrm{kg}\end{array}$} & \multicolumn{2}{|c|}{ Dumpsite soils (T1) } & \multicolumn{2}{|c|}{ Control soils (T2) } \\
\hline & $\mathrm{BP}$ & $\overline{\mathrm{AP}}$ & $\mathrm{BP}$ & $\mathrm{AP}$ \\
\hline Mn & 220.08 & 135.21 & 50.68 & 29.89 \\
\hline $\mathbf{Z n}$ & 135.5 & 88.21 & 29.01 & 15.11 \\
\hline $\mathrm{Cu}$ & 86.88 & 50.22 & 8.92 & 3.89 \\
\hline $\mathbf{P b}$ & 48.86 & 31.56 & 5.88 & 3.68 \\
\hline $\mathbf{N i}$ & 7.99 & 3.56 & 3.01 & 1.22 \\
\hline Co & 6.88 & 2.68 & 1.7 & 0.67 \\
\hline
\end{tabular}

$\mathrm{BP}$ and AP denotes before and after planting respectively

Table 4: Heavy Metal Concentration in the Riccinus communis'

\begin{tabular}{lllll}
\multicolumn{4}{c}{ parts } \\
\hline $\begin{array}{l}\text { Heavy } \\
\text { metals } \\
\text { in mg/kg }\end{array}$ & \multicolumn{2}{c}{ Dumpsite soils (T1) } & \multicolumn{2}{l}{ Control soils (T2) } \\
\cline { 2 - 5 } & Shoot & Root & Shoot & Root \\
\hline $\mathbf{M n}$ & 28.22 & 17.25 & 7.80 & 5.65 \\
$\mathbf{Z n}$ & 25.11 & 19.89 & 4.01 & 3.39 \\
$\mathbf{C u}$ & 17.59 & 13.07 & 1.36 & 1.20 \\
$\mathbf{P b}$ & 7.60 & 6.60 & 1.31 & 1.27 \\
$\mathbf{N i}$ & 1.99 & 1.89 & 1.13 & 1.10 \\
$\mathbf{C o}$ & 1.36 & 1.34 & 0.38 & 0.37 \\
\hline
\end{tabular}

Heavy Metal Concentration in the Riccinus communis' parts: Heavy metal concentrations in Riccinus communis' parts after planting from dumpsite and control soils are presented in Table 4. The results showed that there is variation in heavy metal concentrations in the shoot and roots of the plants. The respective heavy metal concentrations in shoots and roots of the plants from dumpsite soils are: Mn (28.22, 17.25); Zn (25.11, 19.89); $\mathrm{Cu}(17.59$, 13.07); $\mathrm{Pb}(7.60,6.60) ; \mathrm{Ni}(1.99,1.89)$ and $\mathrm{Co}(1.36$, 1.34) in $\mathrm{mg} / \mathrm{kg}$ while their respective values from control soils are: $\mathrm{Mn}(7.80,5.65) ; \mathrm{Zn}(4.01,3.39) ; \mathrm{Cu}$

(1.36, 1.20); $\mathrm{Pb}(1.31,1.27)$; Ni $(1.13,1.10)$ and $\mathrm{Co}$ $(0.38,037)$ in $\mathrm{mg} / \mathrm{kg}$. According to Huang et al. (2011) Riccinus communis has widespread root systems that enable it to penetrate into the soil thus absorbing more contaminants from the soil and transport it into its parts, making it a good remediation potential plants when compared with other plants. In this study, Riccinus communis plants accumulated more heavy metals in its shoot than its roots indicating its potential to transfer the heavy metals absorbed through its root from the soil to its different tissue parts. The higher concentration of heavy metals in shoots than roots agreed with similar work conducted by Akintola and Bodede (2019b) on Cederala Odorata plants and Yashim et al (2020) on Riccinus communis but contrary to the findings of Olivares et al. (2013) and Palanivel et al., (2020) that suggested that Riccinus communis accumulates low concentrations of heavy metals in their aerial parts. The orders of the accumulation of the heavy metals concentration in the plants are $\mathrm{Mn}>\mathrm{Zn}>\mathrm{Cu}>\mathrm{Pb}>\mathrm{Ni}>\mathrm{Co}$ and this may be attributed to the level of availability of this metals in the soil.

Table 5: Values of Bioconcentration (BCF) and Translocation (TF) Factors

\begin{tabular}{lllll}
\hline \multirow{2}{*}{$\begin{array}{l}\text { Heavy } \\
\text { metals } \\
\text { in mg/kg }\end{array}$} & \multicolumn{2}{c}{ Dumpsite soils (T1) } & \multicolumn{2}{l}{ Control soils (T2) } \\
\cline { 2 - 5 } & BCF & TF & BCF & TF \\
\hline $\mathbf{M n}$ & 0.34 & 1.59 & 0.45 & 1.38 \\
$\mathbf{Z n}$ & 0.51 & 1.26 & 0.49 & 1.18 \\
$\mathbf{C u}$ & 0.61 & 1.34 & 0.52 & 1.13 \\
$\mathbf{P b}$ & 0.45 & 1.15 & 0.66 & 1.03 \\
$\mathbf{N i}$ & 1.09 & 1.05 & 1.01 & 1.04 \\
$\mathbf{C o}$ & 1.11 & 1.03 & 1.05 & 1.03 \\
\hline
\end{tabular}

Remediation Potential ofRiccinus communis plants:Bioconcentration (BCF) and translocation (TF) factors are important evaluation indices used to assess the remediation potentials of plant. Mo et al (2008) stated that TF is more of an indicator that reflects that transfer of elements from the roots to the shoots. The results in Table 5 indicated that Riccinus communis plants have TF between 1.03-1.59 for all the heavy metals determined from both the dumpsite and control soils. This indicates the ability of the plants to transfer the heavy metals absorbed in the roots from the soil to the shoots. Generally TF $<$ indicate the heavy metals are retained in the root while $\mathrm{TF}>1$ indicated that the roots were able to transfer it to the shoots and they are more concentrated in the shoots (Olivares et al., 2013). In this study, TF>1 agreed with similar work conducted by Yashim et al, (2016) but higher than the TF obtained by Olivares et al., (2013) and Palanivel et al., (2020) for $\mathrm{Zn}, \mathrm{Cu}, \mathrm{Pb}$, and $\mathrm{Ni}$ of the same plants. Bioaccumulation factor (BCF), which is the ratio of heavy metal concentration in plants to soil was used to assess the effectiveness if the studied plants for heavy metal uptake. The BCF values of the heavy metals are between 0.45-0.66 for $\mathrm{Mn}, \mathrm{Zn}, \mathrm{Cu}$ and $\mathrm{pb}$ and 1. 011.11 for $\mathrm{Ni}$ and $\mathrm{Co}$ in all the soils used (Table 5). The $\mathrm{BCF}$ for $\mathrm{Ni}$ and $\mathrm{Co}$ were greater than 1 while that of $\mathrm{Mn}, \mathrm{Zn}, \mathrm{Cu}$ and $\mathrm{Pb}$ were less than 1 . The $\mathrm{BCF}>1$ for Niagreed with the work of Yashim et al, (2016) while the values of $\mathrm{BCF}<1$ for $\mathrm{Zn}, \mathrm{Cu}$ and $\mathrm{Pb}$ agreed with the findings of Palanivel et al., (2020). However, Cluis 
(2004) stated that plants with BCF $>1$ is considered as hyperaccumulators. Thus, this result indicated that Riccinus communis plants are hyperaccumulator for $\mathrm{Ni}$ and $\mathrm{Co}$. Though, the plants may not be considered as hyperaccumulator for other heavy metals but their enrichment in the plant's tissues is an indication of their bioavalailabilty since they crossed the cellular membrane (Lago-vila et al., 2014). The results of study suggested that Riccinus communis plants can accumulate several heavy metals in its roots and transfer them to its shoots, thus decreasing the heavy metal bioavailability and their dispersal.

Conclusions: This study showed that heavy metal concentrations in the dumpsite were higher than the control site which implies that the deposited wastes have significantly contributed to the heavy metals contribution and can be of health risks to surrounding crops and water resource. Riccinus communis plants showed significant accumulation of heavy metals in the dumpsite than control soil. Also, concentrations of these heavy metals were more in the shoots of the plants than the roots. Results of this study indicate the accumulation of heavy metals in Ricinus communis plants and its potential for effective removal of $\mathrm{Cu}, \mathrm{Zn}$, $\mathrm{Pb}, \mathrm{Ni}, \mathrm{Co}$ and $\mathrm{Mn}$ from the dumpsite soils.

\section{REFERENCES}

Adamcova, D; Radziemaska, M; Ridoskova, A; Barton, S;Pelcova, P; Elbl, J; Kynicky, J; Brtnicky, M; Vaverkov MD (2017). Environmental assessment of the effects of a municipal landfill on the content and distribution of heavy metals in Tanacetum vulgare $\mathrm{L}$. Chemosph.185:1011-1018.

Akintola, OO; Akintola, AI; Abiola, IO; Abodunrin, EK; Ekaun, AA; Adekoya, O, Smart, M (2020). Heavy Metal Assessment of Soils and Vegetables Grown around Awotan Dumpsite. Proceedings of International Medical Geology AssociationNigeria (IMGA).

Akintola, OO; Bodede, IA (2019a). Human health risk assessment of heavy metals in soils around Ajakanga dumpsite, Ibadan Southwestern Nigeria. Proceedings of International Medical Geology Association- Nigeria (IMGA).

Akintola, OO; Bodede, IA (2019b). Distribution and Accumulation of Heavy Metals in Red Cedar (Cedrela odorata) Wood Seedling Grown in Dumpsite Soil. J. Appl. Sci. Environ. Manage. 23 (4):811-817.
Akintola, OO (2014). Geotechnical and Hydrogeological assessment of Lapite waste dumpsite in Ibadan, Southwestern Nigeria. Unpublished $\mathrm{PhD}$ Thesis, University of Ibadan, 307pp.

Bartkowiak, A; Lemanowicz, J; Siwik-Ziomek, A. (2016). Assessment of selected heavy metals and enzymes in soil within the range of impact of illegal dumping sites. Int. J. Environ. Res.10:245254.

Bauddh, K; Singh, K; Singh, B; Singh, RP (2015). Ricinus communis: a robust plant for bio-energy and phytoremediation of toxic metals from contaminated soil. Ecol Eng. 84:640-652/

Brown, RB. (2009). Soil Texture. Institute of Food and Agricultural Sciences (IFAS), University of Florida Accessed through http://www.edis.ifas.ufl.edu/pdffiles on15/04/2020.

Cluis, C (2004). Junk-greedy greens: phytoremediation as a new option for soil decontamination. Bio. Tech. J. 2: 1-67

Ewemoje, TA; Ewemoje, OE; Majolagbe, SP (2017). Urbanization Effects on Surface and Groundwater Resources: An Assessment of Approved Dumpsite in Ibadan, Nigeria. An ASABE meeting presentation. DOI: 10.13031/aim.201701388.

Famuyiwa, AO; Lanre-Iyanda, YA; Osifeso, O (2018). Impact of land use on concentrations of potentially toxic elements in urban soils of Lagos, Nigeria. J. health poll. 8 (19): 105-112.

Ganiyu, SA; Badmus, BS, Oladunjoye, MA; Aizebeokhai, AP; Ozebo, VC; Idowu, OA; Olurin OT (2016). Assessment of groundwater contamination around active dumpsite in Ibadan southwestern Nigeria using integrated electrical resistivity and hydro-chemical methods. Environ Earth Sci. 9:75:643 DOI

Gaur A; Adholeya A (2004). Prospects of arbuscular mycorrhizal fungi in phytoremediation of heavy metal contaminated soils. Curr Sci 86: 528-534.

Gworek, B; Dmuchowski, W; Koda, E; Marecka, M; Baczewska, AH; Bra goszewska, P; Sieczka, A; Osinski, P. (2016). Impact of the municipal solid waste Łubna Landfill on environmental pollution by heavy metals. Water 8:470-478. 
Hu, Z; Wang, C; Li, k; Zhu, X (2018). Distribution characteristics and pollution assessment of soil heavy metals over a typical nonferrous metal mine area in Chifeng, Inner Mongolia, China. Environ Earth sci. 77, 638-648.

Jacob, JM; Karthik, C; Saratale, RG; Kumar, SS; Prabakar, D; Kadirvelu, K; Pugazhendhi, A (2018). Biological approaches to tackle heavy metal pollution: a survey of literature. J. Environ. Manage. 217:56-70.

Lago-Vila, M; Arenas-Lago D; Andrade, L; Vega, FA (2014). Phytoavailable content of metals in soils from copper mine tailings. J. Geochem. Explor. 147:159-166.

Mertens, J; Luyssaert, S; Verheyen, K (2005). Use and abuse of trace metal concentrations in plant tissue for biomonitoring and phytoextraction. Environ. Pollut. 138:1-4.

Nawrot, N; Wojciechowska, E; Matej-Łukowicz, K; Walkusz-Miotk, J; Pazdro, K (2019). Heavy metal accumulation and distribution in Phragmites australis seedlings tissues originating from natural and urban catchment. Environ. Sci. Pollut. Res.5:1-11.

Ogunseiju, P; Ajayi, RF; Olanrewaju, VO (2015). Trace Metals and Hydraulic Characterization of Soils and Groundwater Around Ajakanga Dumpsite in Ibadan Metropolis, Southwest Nigeria. J. Environ. Earth Sci. 5(22): 75-94.

Olivares, AR; Carrillo-gonzalez, R; Gonzalez-chavez, MDCA; Hernandez, RMS (2013). Potential of castor bean (Ricinus communis L.) for phytoremediation of mine tailings and oil production. J. Environ. Manage. 114:316-323
Palanivell, TM; Praceju, B; Victor,R (2020). Phytoremediation potential of castor (Ricinus communis L.) in the soils of the abandoned copper mine in Northern Oman: implications for arid regions. Environ. Sci. Poll. Res. https://doi.org/10.1007/s11356-020-08319-w.

Stoltz, E; Greger, M (2002). Accumulation properties of $\mathrm{As}, \mathrm{Cd}, \mathrm{Cu}, \mathrm{Pb}$ and $\mathrm{Zn}$ by four wetland plant species growing on submerged mine tailings. Environ. Exp. Bot. 47:271-280.

Walkley, A; Black IA (1934). An examination of the Degtjareff method for determining soil organic matter, and a proposed modification of the chromic acid titration method. Soil Sci. 37:29-38.

Yashim, ZI; Agbaji, CR; Gimbal, CE; Idris, I (2016). Phytoremediation Potential of Ricinus communis L. (Castor Oil Plant) in Northern Nigeria. Inter. J. Plant Soil Sci. 10(5): 1-8.

Yin, H; Tan, N; Liu, C; Wang, J; Liang, X; Qu, M; Feng, X; Qiu, G; Tan, W; Liu, F (2016.) The associations of heavy metals with crystalline iron oxides in the polluted soils around the mining areas in Guangdong Province, China. Chemosphere 161, 181e189.

Zhu, J; Wang, Q; Yu, H; Li, M; He, N (2016). Heavy metal deposition through rainfall in Chinese natural terrestrial ecosystems: evidences from national-scale network monitoring. Chemosphere $164,128 \mathrm{e} 133$. 